\title{
Phosphorylation of Estrogen Receptor $\beta$ at Serine 105 Is Associated with Good Prognosis in Breast
} Cancer

\author{
Werbena Hamilton-Burke, ${ }^{*}$ Louise Coleman, ${ }^{*}$ \\ Michele Cummings, ${ }^{\star}$ Caroline A. Green, ${ }^{*}$ \\ Deborah L. Holliday, ${ }^{*}$ Kieran Horgan, ${ }^{\dagger}$ \\ Loaie Maraqa, ${ }^{*}$ Mark B. Peter, ${ }^{*}$ Steven Pollock, ${ }^{*}$ \\ Abeer M. Shaaban, ${ }^{\ddagger}$ Laura Smith, ${ }^{*}$ \\ and Valerie Speirs* \\ From the Leeds Institute of Molecular Medicine," University of \\ Leeds, Leeds; the Leeds General Infirmary, ${ }^{\dagger}$ Leeds; and the St. \\ James's Institute of Oncology, ${ }^{\neq}$Leeds, United Kingdom
}

Estrogen receptor (ER) action is modulated by posttranslational modifications. Although ER $\alpha$ phosphorylation correlates with patient outcome, $\operatorname{ER} \beta$ is similarly phosphorylated but its significance in breast cancer has not been addressed. We investigated whether ER $\beta$ that is phosphorylated at serine 105 (S105-ER $\beta)$ is expressed in breast cancer and assessed potential clinical implications of this phosphorylation. Following antibody validation, S105-ER $\beta$ expression was studied in tissue microarrays comprising 108 tamoxifen-resistant and 351 tamoxifen-sensitive cases and analyzed against clinical data. S105-ER $\beta$ regulation in vitro was assessed by Western blot, flow cytometry, and immunofluorescence. Nuclear S105-ER $\beta$ was observed in breast carcinoma and was associated with better survival (Allred score $\geq 3$ ), even in tamoxifen-resistant cases, and additionally correlated with ER $\beta 1$ and ERß2 expression. Distinct S105-ER $\beta$ nuclear speckles were seen in some higher grade tumors. S105-ER $\beta$ levels increased in MCF-7 cells in response to $17 \beta$-estradiol, the ER $\beta$-specific agonist diarylpropionitrile, and the partial ER $\beta$-agonist genistein. S105-ER $\beta$ nuclear speckles were also seen in MCF-7 cells and markedly increased in size and number at 24 hours following $17 \beta$-estradiol and, in particular diarylpropionitrile, treatment. These speckles were coexpressed with ER $\beta 1$ and ER $\beta 2$. Presence of S105-ER $\beta$ in breast cancer and association with improved survival, even in endocrine resistant breast tumors suggest S105-ER $\beta$ might be a useful additional prognostic marker in this disease. (Am J Pathol 2010, 177:1079-1086; DOI: 10.2353/ajpath.2010.090886)
Two estrogen receptors (ERs) are expressed in breast cancer, $\mathrm{ER} \alpha$ and $\mathrm{ER} \beta$. $^{1}$ The former determines the likelihood of patients to respond to adjuvant endocrine therapy such as tamoxifen and aromatase inhibitors while the latter exists as five functionally distinct isoforms. ${ }^{2-4}$ These have differing prognostic significances in breast cancer, which is also dictated by their cellular location. ${ }^{5-7}$

It is well established that $\mathrm{ER} \alpha$ activity is regulated at multiple levels including posttranslational modifications such as phosphorylation with several phosphorylation sites identified. ${ }^{8,9}$ In the case of ER $\alpha$ both serine and tyrosine residues have been implicated in ligand dependent and independent phosphorylation. ${ }^{10-13}$ In particular S118 and S167 phosphorylation have been associated with clinical outcome; the former predicts good outcome in non-selected cohorts ${ }^{14}$ and also in patients treated with tamoxifen. ${ }^{15,16}$ Similarly $\mathbf{S} 167$ expression signifies increased disease-free and overall survival ${ }^{17}$ and can predict responses to endocrine therapy. ${ }^{18}$ Other studies have reported paradoxical results regarding S118 ER $\alpha$ phosphorylation, showing high expression in more differentiated tumors, and also elevation in tumor biopsies from patients who had relapsed on tamoxifen, suggesting that increased $\mathrm{S} 118 \mathrm{ER} \alpha$ phosphorylation may be involved in the development of endocrine resistance. ${ }^{19}$ Clinical and laboratory data suggest this may also may the case with $\mathrm{S} 305 \mathrm{ER} \alpha$ phosphorylation. ${ }^{20}$ An investigation on S118 and S167 ER $\alpha$ phosphorylation indicated that combined activities of these phosphoproteins may be more effective in determining patient outcome, with low S118 and high S167 ER $\alpha$ phosphorylation associated with better disease-free and overall survival. ${ }^{21}$

Supported by the Breast Cancer Campaign (V.S., D.L.H., S.P., L.S.), Cancer Research UK (V.S., M.C.), Leeds Teaching Hospitals NHS Trust Breast Fund (V.S., W.H.B., L.M., M.B.P.), and a University of Leeds Ph.D. scholarship (C.A.G.).

Accepted for publication May 11, 2010.

Supplemental material for this article can be found on http://ajp. amjpathol.org.

Address reprint requests to Valerie Speirs, Ph.D., Leeds Institute of Molecular Medicine, Wellcome Trust Brenner Building, St. James's University Hospital, Leeds LS9 7TF, UK. E-mail: v.speirs@leeds.ac.uk. 
Studies on murine ER $\beta$ have revealed this is similarly phosphorylated $\mathrm{d}^{22-24}$ and some of the phosphorylated residues correspond to the same residues in human ER $\beta .^{25,26}$ In particular, it has been shown that EGF and Ras enhance $17 \beta$-estradiol (E2)-induced transcriptional activity of murine ER $\beta$ via MAPK-directed phosphorylation of serines 106 and 124 within the AF-1 domain, and recruitment of the co-activators $\mathrm{SRC}-1$ and $\mathrm{CBP} .{ }^{23}$ Phosphorylation of these sites can also mediate ligandindependent transcriptional activity of ER $\beta .^{27}$ Alignment of murine and human ER $\beta$ protein sequences (NP_997590.1 and NP_001428, respectively) show conservation of the S124 MAPK phosphorylation site in human $E R \beta$, and that human $\mathrm{S} 105$ is equivalent to murine S124 (see Supplemental Figure 1 at $h t t p: / / a j p$. amjpathol.org). Recently, an antibody to this phosphorylation site has become available. Following comprehensive validation of this antibody, the aim of our study was to determine whether ER $\beta$ phosphorylated at S105 $(\mathrm{S} 105-\mathrm{ER} \beta)$ is expressed in breast cancer, to assess its potential clinical implications in endocrine sensitive and resistant breast tumors, and finally to explore its activity in vitro.

\section{Materials and Methods}

\section{Ethical Considerations}

Ethical approval was obtained from the Leeds (East) Local Research Ethics Committee at St James's University Hospital, Leeds, UK (reference 06/Q1206/180).

\section{Sequence Alignment}

Pairwise alignment of NP_997590.1 (murine ERß1) and NP_001428 (human ER $\beta$ ) was performed using Blastp (http://blast.ncbi.nlm.nih.gov/Blast.cgi date last accessed, July 4, 2009).

\section{siRNA Silencing and Preparation of Cell Blocks}

ER $\beta$ silencing was achieved by transient transfection of MCF-7 cells with SMARTpool ON-TARGET plus RNA duplexes against total ER $\beta$ (Dharmacon, UK) using Oligofectamine (Invitrogen, Paisley, UK) according to the manufacturer's instructions. An siRNA pool of non-targeting sequences was used as a negative control (Dharmacon, D-001206-13). Efficacy of knockdown was determined using quantitative real time RT-PCR as previously described. ${ }^{28}$ Formalin-fixed paraffin-embedded (FFPE) cell blocks of MCF-7 cells in which ER $\beta$ was silenced (including appropriate controls) and BT-20 cells were prepared as previously described. ${ }^{29}$

\section{Antibody Validation}

A rabbit polyclonal antibody against S105-ER $\beta$ (AbCam, Cambridge, UK) was used at 1:25. Specificity in tissue sections was determined by pre-treating with $\lambda$ protein phosphatase (4800U; New England Biolabs, Hitchin,
UK). FFPE cell blocks in which ER $\beta$ had been silenced (described above) served as additional validation. S105ER $\beta$ was also validated by Western blotting. Total proteins were extracted, processed, and analyzed as previously described ${ }^{28}$ from MCF-7 cells treated with or without $10 \mathrm{nmol} / \mathrm{L}$ E2 or diarylpropionitrile (DPN; Tocris Bioscience, Bristol, UK) for up to 24 hours in phenol red-free RPMI media (Invitrogen) containing 5\% charcoal stripped fetal calf serum. Blots were incubated at $4^{\circ} \mathrm{C}$ for $>15$ hours with S105-ER $\beta$ antibody, ER $\beta 1$ (Serotec, Oxford, UK; both 1:250) or 1:1000 S118-ER $\alpha$ (Cell Signaling, Danvers, MA), all diluted in $0.5 \%$ bovine serum albumin. Following further washing, blots were incubated with polyclonal swine anti-rabbit immunoglobulin/horseradish peroxidase (Dako, Ely, UK). Horseradish peroxidase was visualized using SuperSignal West Pico ECL reagent (ThermoFisher, Loughborough, UK) on Hyperfilm-ECL (GE Life Sciences, High Wycombe, UK). Loading control was assessed using $\beta$-actin (1: 20,000; Sigma, Poole, UK). Two independent blots were performed.

\section{Quantification of S105-ER $\beta$ Expression Using Flow Cytometry}

With appropriate vehicle controls, log phase MCF-7 cells were treated with $10 \mu \mathrm{mol} / \mathrm{L}$ genistein (Sigma) or 10 nmol/L DPN for 24 hours then harvested using trypsin/ EDTA. Cells were re-suspended in PBS and fixed with $1 \%$ paraformaldehyde (Sigma) for 40 minutes at $4^{\circ} \mathrm{C}$ followed by permeabilization in $0.5 \%$ saponin (Sigma) for $10 \mathrm{~min}$ utes at $4^{\circ} \mathrm{C}$. Cells, $5 \times 10^{5}$, were transferred to polypropylene tubes and washed twice with PBS $+1 \%$ fetal calf serum. Total ER $\beta$ (14C8, AbCam; $2.5 \mu l$ ) and P-S105-ER $\beta$ (AbCam; $5 \mu \mathrm{l}$ ) were added to the cell suspension and incubated for 30 minutes at $4^{\circ} \mathrm{C}$. Labeled cells were washed twice and incubated for 1 hour at $4^{\circ} \mathrm{C}$ with fluorescein isothiocyanate-conjugated secondary antibodies (rabbit anti-mouse 1:50, swine anti-rabbit 1:100; both Sigma). Appropriate controls were analyzed in parallel. Samples were stored overnight in the dark at $4^{\circ} \mathrm{C}$ then analyzed using an LSRII flow cytometer (BD, Oxford, UK) on pre-stored instrument settings. Protein activity was determined by multiplying the shift of the test antibody from respective IgG controls within a gated region M1 with the proportion of cells in S-phase (used to indicate the rate of cell proliferation). Each experiment was performed in triplicate.

\section{Clinical Cohorts, Tissue Microarray (TMA) Construction and Immunohistochemistry}

Clinicopathological characteristics of the cohort have already been described. ${ }^{24,25}$ TMAs were prepared using 0.6- $\mathrm{mm}$ cores selected from the most representative tumor areas and immunohistochemical analysis of $4-\mu \mathrm{m}$ TMA sections was performed using standard techniques as previously described. ${ }^{28,30} \mathrm{~S} 105-\mathrm{ER} \beta$ antibody was diluted 1:25 and incubated overnight at $4^{\circ} \mathrm{C}$. Negative controls in which primary antibody was omitted and pos- 
itive controls of breast carcinoma of varying staining intensities were included in each batch of immunohistochemistry.

\section{Immunohistochemical Evaluation}

TMA images were digitized (Aperio Technologies, Vista, $\mathrm{CA}$ ) and nuclear immunoreactivity was scored using the Allred score based on nuclear staining intensity and proportion of positively stained nuclei, generating a numerical value from 0 to 8 used previously for $E R \beta$ isoforms. ${ }^{6}$ Cases were scored by W.H.B. and A.M.S. (a specialized consultant breast histopathologist).

\section{Single and Dual Immunofluorescence}

E2-depleted MCF-7, $2 \times 10^{5}$ cells $/ \mathrm{ml}$, were seeded in coverslips in six-well plates. After overnight attachment cells were treated with either $10 \mathrm{nmol} / \mathrm{L}$ E2 or DPN (Tocris) for 15, 30, or 60 minutes and 24 hours with appropriate vehicle controls. Cells were fixed with freshly prepared $2 \%$ paraformaldehyde for 20 minutes at room temperature. Permeabilization was achieved using 0.05\% Triton X-100 (Sigma; 10 minutes) and nonspecific proteins were blocked using $2 \%$ bovine serum albumin in PBS (10 minutes). Cells were then incubated overnight at $4^{\circ} \mathrm{C}$ with S105-ER $\beta$ antibody (1:25). Following PBS washes secondary antibody (Alexa Fluor 594 goat antirabbit IgG $(\mathrm{H}+\mathrm{L})$; Invitrogen) was applied (1:500; 60 minutes at room temperature). After further PBS washes, coverslips were mounted on microscope slides using DAPI-containing Vectashield (Vector, Peterborough, UK). Coexpression of S105-ER $\beta$ with ER $\beta 1$ or ER $\beta 2$ was assessed with concomitant incubation of the cells with antiS105-ER $\beta$ and anti-ER $\beta 1$ or anti-ER $\beta 2$ (both from Serotec). Cells were visualized on a Zeiss Axiovert 200 microscope. Image acquisition was controlled by Andor IQ software (Nottingham, UK). Controls included substitution of primary antibody with an irrelevant matched IgG subtype.

\section{Statistical Analysis}

Pearson's $\chi^{2}$ test or Fisher's exact test were performed to demonstrate relationships between immunohistochemical findings and clinicopathological variables. Correlations were assessed using Spearman's rank correlation test. Survival analyses were performed using KaplanMeier curves and log rank test with an Allred score of $\geq 3$ determining positivity. Cox proportional hazards model was used to test the statistical independence and significance of predictors DFS and OS adjusted for other prognostic indicators (tumor size, grade, lymph node and ER $\alpha$ status). SPSS (version 15) was used for all analyses. $P<$ 0.05 was considered significant.
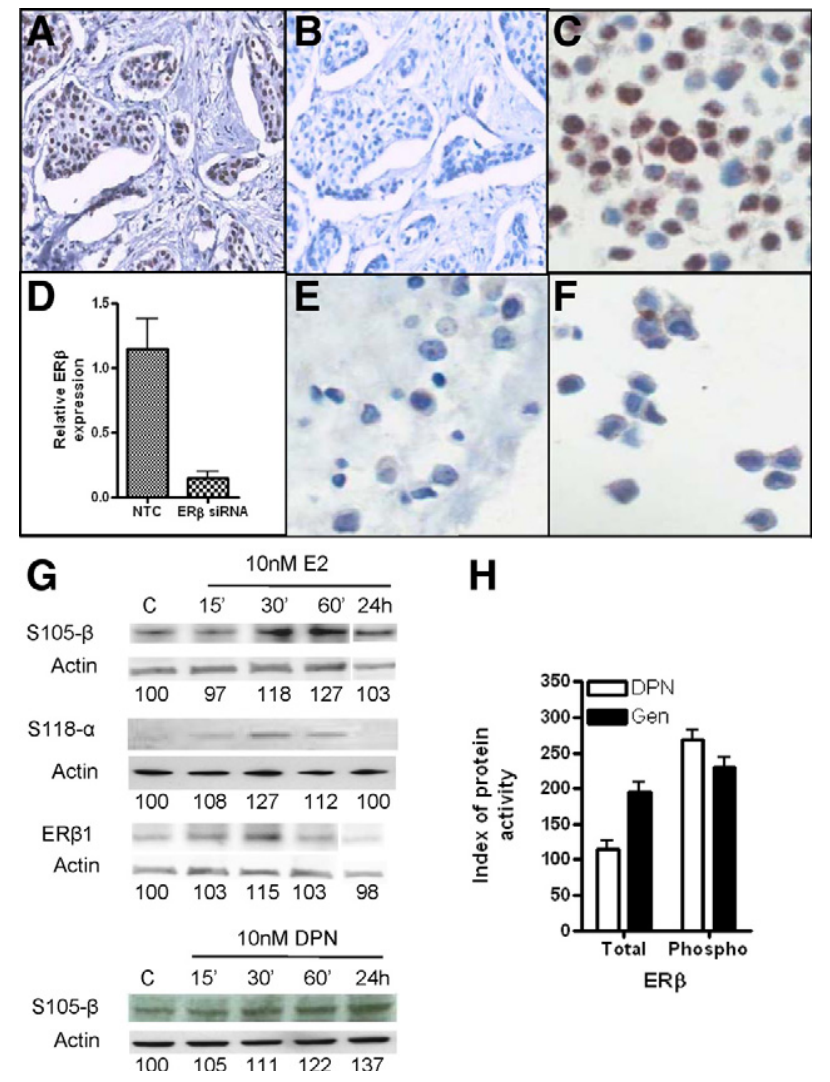

H

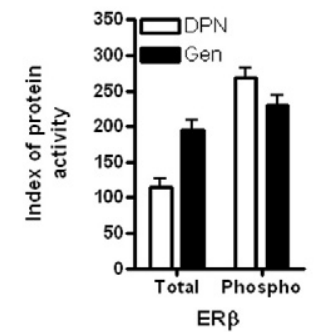

Figure 1. Nuclear S105-ER $\beta$ (A) was completely abolished following phosphatase pretreatment of serial sections (B). S105-ER $\beta$ was expressed in MCF-7 cells (C) but following siRNA silencing (D) expression was abolished (E). No expression was detected in BT-20 cells $(\mathbf{F})$. Original magnifications, $\times 20(\mathbf{A}, \mathbf{B}) ; \times 40(\mathbf{C}, \mathbf{E}, \mathbf{F})$. By Western blot, S105-ER $\beta$ antibody recognized a specific protein in MCF-7 cells, which was increased in response to 10 $\mathrm{nmol} / \mathrm{L} \mathrm{E} 2$, and to a lesser extent DPN, in a time-dependent manner (G, S105- $\beta$ ). A more rapid response was seen with S118-ER $\alpha$ (S118- $\alpha$ ), whereas ER $\beta 1$ expression was largely unchanged. $\beta$-Actin showed equivalent loading in all samples. Figures below each blot represent percentage of protein expressed compared with control, quantified using Quantity One software (Bio-Rad). Flow cytometric analysis of total and S105-ER $\beta$ in response to DPN (white bars) MCF-7 cells showed increased expression of S105-ER $\beta$, whereas genistein (black bars) increased levels of both total and $\operatorname{S105-ER~} \beta(\mathbf{H})$. The $y$ axis refers to the activity of each protein normalized against vehicle control. Each data point is the mean $\pm S D$.

\section{Results}

\section{Antibody Validation}

Immunohistochemical analysis of S105-ER $\beta$ revealed nuclear uniform expression in whole tissue sections (Figure 1A), which was completely abolished when the antibody was preincubated with phosphatase (Figure 1B). As further antibody validation, FFPE blocks of MCF-7 cells showed S105-ER $\beta$ expression in the majority of cells (Figure 1C) while siRNA silencing of $E R \beta$ in these cells (Figure 1D) resulted in abolition of S105-ER $\beta$ signal (Figure 1E). S105-ER $\beta$ expression was not observed in FFPE blocks of ER-negative BT-20 cells (Figure 1F). Western blot revealed $\mathrm{S} 105-\mathrm{ER} \beta$ recognized a single specific protein in MCF-7 cells. Treatment of these cells with 10 $\mathrm{nmol} / \mathrm{L}$ E2 increased expression of S105-ER $\beta$ within 30 minutes, which was sustained for 1 hour, and reduced to control levels by 24 hours, as determined by densitometry. This contrasted S118-ER $\alpha$, whose expression was 
Table 1. Relationship Between S105-ER $\beta$ and Clinicopathological Parameters

\begin{tabular}{|c|c|c|c|c|c|c|c|c|c|}
\hline \multirow[b]{2}{*}{ Parameter } & \multicolumn{2}{|c|}{$\begin{array}{c}\text { Tamoxifen- } \\
\text { sensitive } \\
(n=351) \\
\text { S105-ER } \beta\end{array}$} & \multirow[b]{2}{*}{$P$} & \multicolumn{2}{|c|}{$\begin{array}{c}\text { Tamoxifen- } \\
\text { resistant } \\
(n=108) \\
\text { S105-ER } \beta\end{array}$} & \multirow[b]{2}{*}{$P$} & \multicolumn{2}{|c|}{$\begin{array}{c}\text { Combined } \\
\text { cohort } \\
(n=459) \\
\text { S105-ER } \beta\end{array}$} & \multirow[b]{2}{*}{$P$} \\
\hline & - & + & & - & + & & - & + & \\
\hline \multicolumn{10}{|l|}{$\mathrm{ER} \alpha$} \\
\hline- & 36 & 23 & \multirow[t]{2}{*}{$<0.0001$} & 9 & 25 & \multirow[t]{2}{*}{0.34} & 45 & 48 & \multirow[t]{2}{*}{$<0.001$} \\
\hline $\mathrm{PR}^{+}$ & 35 & 202 & & 7 & 39 & & 42 & 241 & \\
\hline- & 9 & 44 & \multirow[t]{2}{*}{0.26} & 7 & 13 & \multirow[t]{2}{*}{0.44} & 16 & 57 & \multirow[t]{2}{*}{0.05} \\
\hline+ & 26 & 223 & & 10 & 35 & & 36 & 258 & \\
\hline $\mathrm{AR}$ & & & \multirow{3}{*}{0.67} & \multirow{3}{*}{\multicolumn{2}{|c|}{ Not done }} & & \multirow{2}{*}{\multicolumn{2}{|c|}{ Not done }} & \\
\hline- & 1 & 5 & & & & & & & \\
\hline \multicolumn{7}{|l|}{ Grade* } & & & \\
\hline 1 & 2 & 57 & \multirow[t]{3}{*}{0.01} & 1 & 9 & \multirow[t]{3}{*}{0.33} & 3 & 66 & \multirow[t]{3}{*}{0.01} \\
\hline 2 & 22 & 105 & & 9 & 25 & & 31 & 130 & \\
\hline 3 & 12 & 111 & & 13 & 26 & & 25 & 136 & \\
\hline \multicolumn{10}{|l|}{ Size $^{+}$} \\
\hline T1 & 19 & 163 & \multirow[t]{3}{*}{0.16} & 7 & 22 & \multirow[t]{4}{*}{0.19} & 26 & 185 & \multirow[t]{3}{*}{0.12} \\
\hline T2 & 16 & 89 & & 7 & 26 & & 23 & 115 & \\
\hline T3 & 0 & 15 & & 9 & 12 & & 9 & 27 & \\
\hline \multicolumn{9}{|l|}{$\mathrm{LN}^{\ddagger}$} & \\
\hline- & 19 & 119 & \multirow{2}{*}{0.43} & 3 & 17 & \multirow[t]{2}{*}{0.27} & 22 & 136 & \multirow{2}{*}{0.82} \\
\hline+ & 16 & 142 & & 16 & 35 & & 32 & 177 & \\
\hline
\end{tabular}

Information was not available for: 42 and $25,{ }^{*} 50$ and $25,{ }^{\dagger}$ and 55 and $37^{\ddagger}$ from the sensitive and resistant cohorts, respectively. From the original total of 459 cases, immunohistochemical data were available on a maximum of 384 cases due to loss of some TMA cores during antigen retrieval and staining, a well-recognized phenomenon associated with TMA immunohistochemistry and comparable with other studies. ${ }^{6}$

more rapidly induced within 15 minutes. ER $\beta 1$ expression increased 30 minutes post-E2, reaching control levels after 1 hour (Figure 1G). S105-ER $\beta$ expression gradually increased following DPN treatment with maximal expression at 24 hours (Figure 1G). The relationship between S105-ER $\beta$ expression with clinicopathological parameters in shown in Table $1 .{ }^{6} \mathrm{~S} 105-\mathrm{ER} \beta$ positivity was comparable in both cohorts.

\section{Quantification of S105-ER $\beta$ Expression in Response to ER $\beta$ Agonists Using Flow Cytometry}

To further examine the effects of known ER $\beta$ agonists, genistein and DPN on total ER $\beta$ and S105-ER $\beta$ expression in MCF-7 cells, flow cytometry experiments were performed. When normalized to the relevant vehicle control, the specific ER $\beta$ agonist DPN increased levels of S105-ER $\beta$ by 2.6-fold, comparable to the Western data shown above. This was not observed with total ER $\beta$. Genistein increased levels of expression of both total and S105-ER $\beta$ by approximately twofold (Figure $1 \mathrm{H}$ ).

\section{S105-ER Predicts Better Prognosis in Breast Cancer}

Since uniform S105-ER $\beta$ staining was seen in full tissue sections all subsequent staining was conducted using TMAs. Immunohistochemical analysis of S105-ER $\beta$ in unselected breast cancers revealed mainly nuclear expression (Figure 2A). Allred scores ranged from 0 to 8 (median 6). Distinct nuclear speckling was observed in $45 \%$ of cases (Figure 2B). Expression of S105-ER $\beta$ (Allred score $\geq 3$ ) was associated with improved disease-free and overall survival (Figure $3, A$ and $B$ ). Co-expression of S105-ER $\beta$ with ER $\beta 1$ and $E R \beta 2$ was also associated with
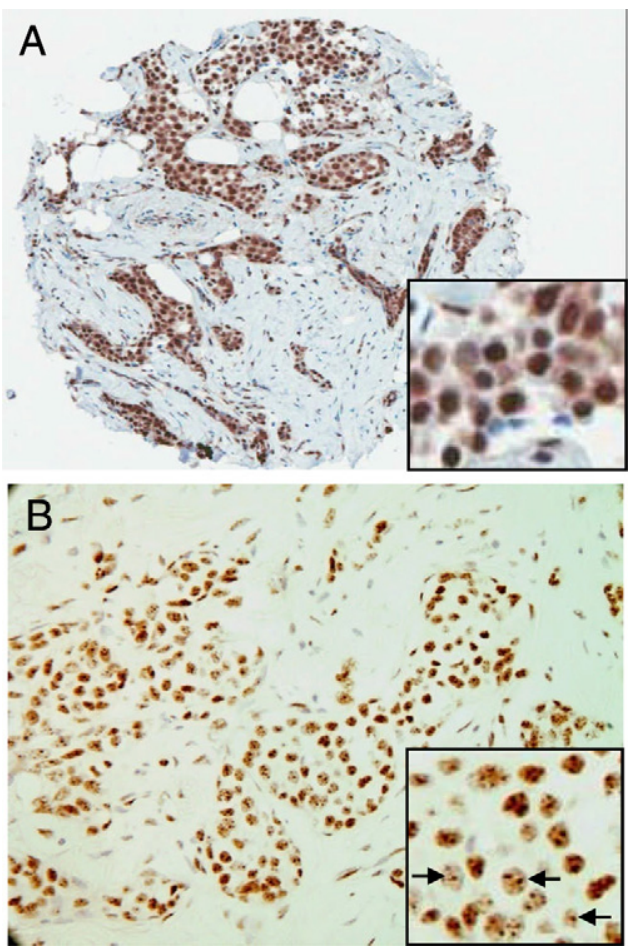

Figure 2. $\mathrm{S} 105-\mathrm{ER} \beta$ is expressed in the nucleus of breast cancer epithelial cells (A). In some cases nuclear speckling was observed (B). Higher power images are shown in the insets. Arrows depict nuclear speckles. Original magnification, $\times 20$; insets, $\times 40$ 
A

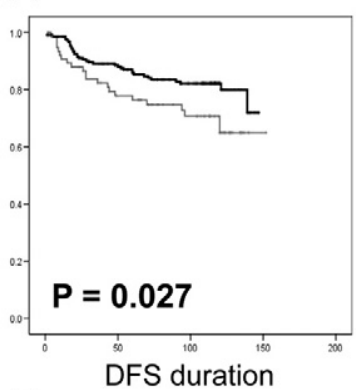

C

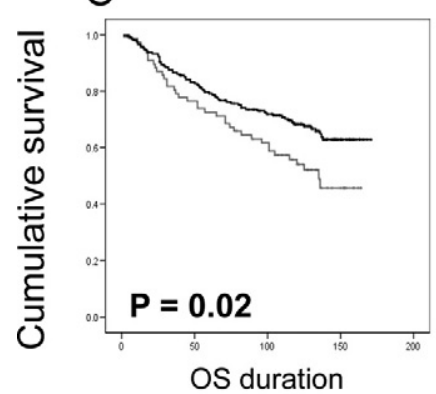

E

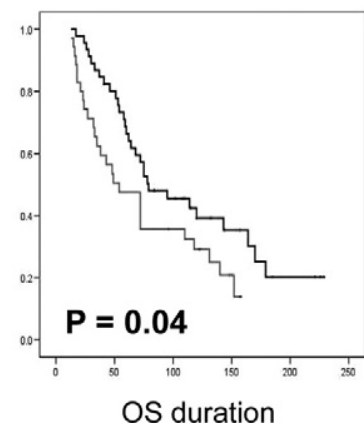

B

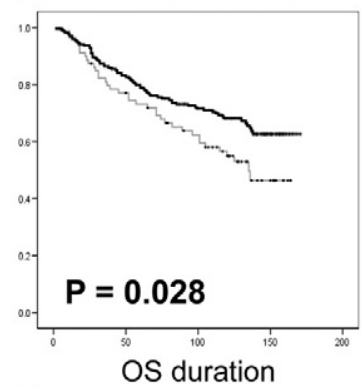

D

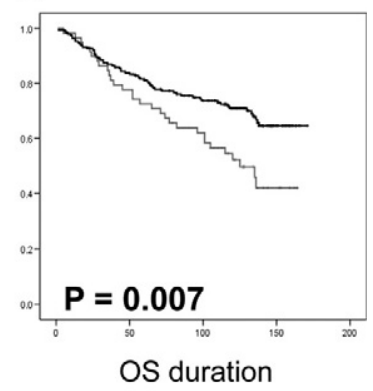

$\mathrm{F}$

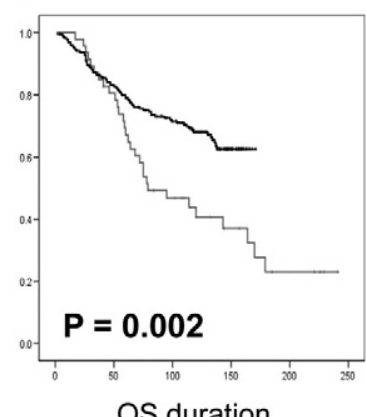

Figure 3. Kaplan-Meier survival curves showing disease-free (A) and overall (B) survival according to S105-ER $\beta$ expression determined by Allred cutoff $\geq 3$ and depicted by the dark lines. Improved disease-free (not shown) and overall survival was seen in ER $\beta 1$-positive tumors $(\mathbf{C})$ and ER $\beta 2$-positive tumors (D). S105-ER $\beta$ expression is indicated by dark lines. S105-ER $\beta$ expression in endocrine-resistant cancers was associated with better overall survival (E); however, direct comparison of cases expressing S105-ER $\beta$ from the tamoxifen-sensitive (dark line) and resistant (pale line) cohorts showed that the latter had worse survival $(\mathbf{F}) . P$ value $=\log$ rank test.

improved disease-free (not shown) and overall survival (Figure 3, C and D). In a multivariate Cox hazard analysis, S105-ER $\beta$ expression was a significant predictor of better OS and DFS independent of tumor grade, lymph node status, size, or ER $\alpha$ status. In endocrine-resistant breast cancers, cases expressing S105-ER $\beta$ were associated with better overall survival; however, direct comparison of cases from the tamoxifen-sensitive and resistant cohorts which expressed S105-ER $\beta$ showed that the latter had worse survival (Figure 3, E and F). Correlations between S105-ER $\beta$ expression and $\operatorname{ER} \alpha(P<0.0001)$ and low tumor grade $(P<0.015)$ were observed in the tamoxifensensitive but not the tamoxifen-resistant cohort (Table 1). ${ }^{6}$ In the combined dataset significant correlations were observed with $\mathrm{ER} \alpha(P<0.0001)$ and low grade $(P=$ $0.015)$ with $\mathrm{PR}$ showing a trend toward significance $(P=$ 0.05). No significant correlation of S105-ER $\beta$ expression

with age, tumor size, $\mathrm{PR}$, and AR expression was observed. Presence of S105-ER $\beta$ nuclear speckles was significantly associated with higher grade tumors $(P<$ 0.0001 ) and was seen in some but not all tamoxifenresistant cases. No further associations were observed for other clinicopathological variables or with survival.

\section{Immunofluorescence Reveals S105-ER $\beta$ Nuclear Speckles Are Increased by E2 and DPN Exposure in MCF-7 Cells}

As with clinical samples, S105-ER $\beta$ nuclear speckles were also observed in MCF-7 cells using immunofluorescence. As S105-ER $\beta$ protein expression was affected by hormones (Figure 1) we wished to establish if there was a hormonal effect on nuclear speckles. These were markedly increased in size and number at 24 hours following E2 (Figure 4, A-D) and, in particular, DPN, where speckles appeared to merge into solid nuclear fluorescence in some but not all nuclei (Figure 4, E-H). These speckles were co-expressed with ER $\beta 1$ (Figure 4, I-L) and ER $\beta 2$ (Figure 4, M-P); but while ER $\beta 1$ and -2 expression tended to be more uniform across the nucleus, the S105ER $\beta$ nuclear speckles formed discrete nuclear foci (Figure 40). Small diffuse ER $\beta 2$ speckles were also observed (Figure $4 \mathrm{~N}$ ) but they these did not colocalize with S105ER $\beta$ speckles (Figure 4P; demonstrated further in Supplemental Figure 2 at http://ajp.amjpathol.org).

\section{Discussion}

To our knowledge, this is the first study to show immunohistochemical expression in human breast cancer of S105-ER $\beta$, providing evidence for its potential role in this disease. Moreover we have rigorously validated a new commercially available antibody that detects nuclear immunoreactivity and can be used in formalin-fixed paraffin-embedded samples as well as in Western blots.

As we were using a new antibody, which to our knowledge had not previously been used in the literature, a critical first step was its validation. In full sections, we observed positive predominantly nuclear staining across a range of different breast tumors, selected to account for tumor heterogeneity, which is a common feature in breast cancer. Incubation of S105-ER $\beta$ antibody but not antibodies detecting total ER $\beta$ or ER $\beta 1$ with phosphatase resulted in loss of signal, indicating specificity. Further antibody specificity was provided using FFPE cell blocks of MCF-7 in which ER $\beta$ had been experimentally silenced by siRNA, where S105-ER $\beta$ expression was abolished compared with cells treated with non-targeting control vector. We were unable to obtain the immunizing peptide used to produce the S105-ER $\beta$ antibody for further validation purposes as this was not commercially available.

A common concern with phosphorylated antibodies, which has been raised in the literature with respect to $\mathrm{ER} \alpha$ phosphorylation, is their stability. ${ }^{31}$ Although we did not specifically address stability of the S105-ER $\beta$ epitope, our staining pattern was consistent across our 


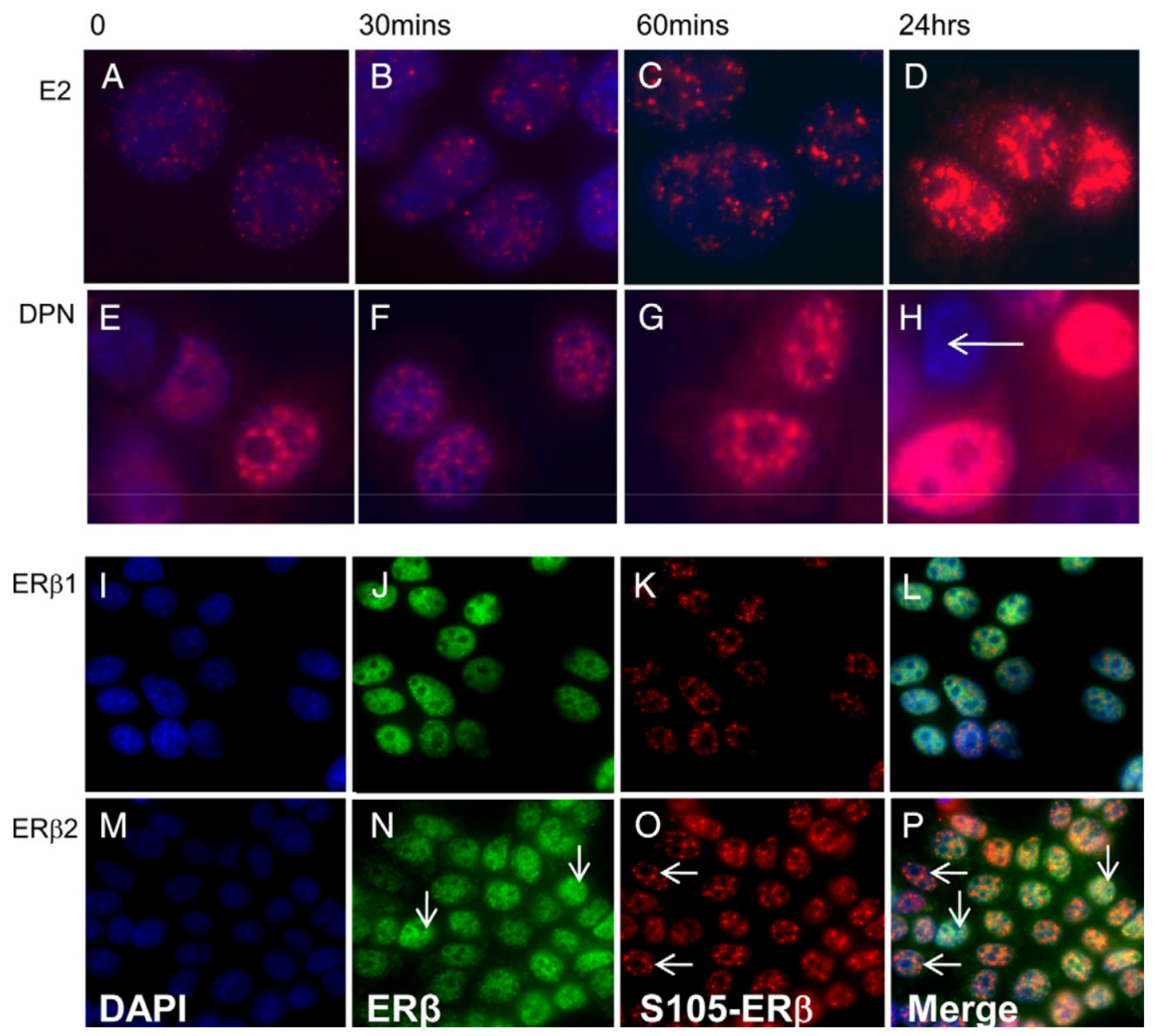

Figure 4. By immunofluorescence, MCF-7 cells displayed S105-ER $\beta$ nuclear speckles, which increased in size and number following E2 (A-D) and DPN (E-H) treatment, although some nuclei were unaffected by DPN treatment (arrow). S105-ER $\beta$ speckles were coexpressed with ER $\beta 1$ (I-L) and ER $\beta 2$ (M-P). In some cells, small ER $\beta 2$ speckles were observed (vertical arrows, $\mathbf{N}, \mathbf{P}$ ); however, these did not colocalize with S105-ER $\beta$ speckles (horizontal arrows, O, P). See Supplemental Figure 2 at http://ajp.amjpathol.org for higher magnification images. Original magnification, $\times 60(\mathbf{A}-\mathbf{H}), \times 20(\mathbf{I}-\mathbf{P})$.

TMAs, which contained cases dating from 1995. These were carefully stored with desiccant at $4^{\circ} \mathrm{C}$. However it is possible that stability of different ER $\beta$ phosphorylation sites could vary; the absence of another phosphorylated $\mathrm{ER} \beta$ antibody precludes us from testing this hypothesis.

S105-ER $\beta$ antibody specificity was further confirmed by Western blot of MCF-7 extracts where a single band of the predicted size was observed. Although this was detected under basal conditions, this is not unusual for antibodies that detect phosphoproteins and could be explained by the fact that we used a high-sensitivity secondary detection reagent, as our previous experience with $\mathrm{ER} \beta$ antibodies ${ }^{32}$ and anecdotal reports from others indicates that these can be particularly challenging in Western blots. Nevertheless, S105-ER $\beta$ signal was strongly increased above baseline in response to E2 with effects observed after 30 minutes and sustained up to 1 hour. This is slower than ER $\alpha$ phosphorylation, which is normally a fairly rapid event in vitro usually occurring within 15 minutes, ${ }^{19}$ also demonstrated herein using $\mathrm{S} 118-\mathrm{ER} \alpha$. This could indicate complex ER $\beta$ regulation, which our group has recently reported. ${ }^{33}$ Alternatively, this may depend on the proportion of $E R \beta$ isoforms within a given cell as only ER $\beta 1$ can bind ligand. ${ }^{4}$ Heterodimerization with other non-ligand binding isoforms or with $\mathrm{ER} \alpha,{ }^{34-36}$ which is abundantly expressed in MCF-7, may also influence this. There was an increase in ER $\beta 1$ expression after 30 minutes of E2 but this reached basal level by 60 minutes with no further changes over 24 hours. Using longer incubations (24 hours), Tateishi and colleagues have reported this for both $\mathrm{ER} \alpha^{37}$ and total $\mathrm{ER} \beta^{38}$ providing evidence for proteasome-mediated receptor degradation.

Using both Western blot and flow cytometry we explored the effects of ligands with enhanced specificity for $\mathrm{ER} \beta$ on total and $\mathrm{S} 105-\mathrm{ER} \beta$. DPN is a highly specific ER $\beta$ agonist ${ }^{39}$ and this was reflected in the marked increase in S105-ER $\beta$ following DPN treatment, particularly by flow cytometry. In contrast, the effects of genistein on increasing levels of total as well as S105-ER $\beta$ may be explained by its activity as a partial ER $\beta$ agonist, ${ }^{40}$ which has welldocumented multifunctional effects ${ }^{41}$ that seem to be concentration-dependent. ${ }^{42}$ 
In our clinical cohorts, S105-ER $\beta$ was positively associated with improved disease-free and overall survival both in endocrine-sensitive and -resistant cases, although we failed to reveal any statistical correlation of S105-ER $\beta$ expression with age, tumor size, grade, ER $\alpha$, $\mathrm{PR}$, and AR expression. Recent reports have outlined the importance of specific ER $\beta$ isoforms in defining clinical outcome..$^{5-7}$ This study has showed that the added presence of S105-ER $\beta$ can further stratify patients, potentially allowing more precise selection of patient subgroups that will derive optimum benefit from endocrine therapy. Although $\mathrm{ER} \alpha$ and $\mathrm{ER} \beta$ reside on separate genes, ${ }^{1}$ they are related molecules and our observation with $\mathrm{S} 105-\mathrm{ER} \beta$ is in line with some but not all studies relating $E R \alpha$ phosphorylation with better clinical outcome. ${ }^{14-21}$ Since this is the first study describing the association of S105-ER $\beta$ with improved survival it requires confirmation in further independent patient series.

A consistent and unexpected finding was the presence of S105-ER $\beta$ nuclear speckles, observed both in clinical samples and in cell line models. We have previously observed nuclear speckling of ER $\beta 2$ and to a lesser extent ER $\beta 1$ in a range of different cell lines, which is related to gene transcription but not protein synthesis (C.A. Green, E.E. Morrison, A.R. Green, I.O. Ellis, A.M. Shaaban, A.M. Hanby, V. Speirs unpublished observations). In the present study small nuclear speckles were observed for ER $\beta 2$ but were not as pronounced as those seen for S105-ER $\beta$. Further inspection of higher magnification images showed that cells expressed either S105ER $\beta$ or S105-ER $\beta$ nuclear speckles but not both. The nature of these speckles is currently unknown however their clustering into larger aggregates in response to both E2 and DPN ER ligands, in some but not all nuclei could indicate a role in transcriptional regulation. Although literature in this area is sparse, membrane-targeted ER $\alpha$ showed a similar nuclear speckling pattern after E2 treatment. ${ }^{43}$ These authors suggested that nuclear speckles may be associated with endosomes or microsomes. The functional role of both ER $\beta 2$ and S105-ER $\beta$ speckles is the focus of ongoing work in our laboratory.

Murphy and colleagues ${ }^{9,31}$ have suggested that ER $\alpha$ phosphorylation could complement the information provided by ER $\alpha$ regarding treatment response and clinical outcome in breast cancer. We have suggested this for $\mathrm{ER} \beta$ isoforms ${ }^{6}$ and the association of S105-ER $\beta$ with improved breast cancer survival suggests it might be a further additional marker. Since publication of the original 70-gene expression signature, ${ }^{44}$ much has been made of the potential of gene expression profiling to predict clinical outcome ${ }^{45}$; however, platforms such as MammaPrint and OncotypeDx are expensive, require specialized equipment and are not yet widely available. Significantly, gene expression does not always correlate with that of protein, the functional output of cells. Perhaps we need to take a step back and consider the potential of profiling the phosphorylation status of $E R \alpha / \beta$ in breast tumors using tried and tested immunohistochemical techniques, with robust antibodies in an effort to define subgroups of patients who might benefit from specific therapies. This recommendation has recently been put forward in the context of "combinatorial biomarker expression." ${ }^{46}$ Indeed while this work was under review an $\mathrm{ER} \alpha$ phosphorylation code incorporating $7 \mathrm{ER} \alpha$ phosphorylation sites was described, which is predictive of response to endocrine therapy in breast cancer. ${ }^{47}$

\section{References}

1. Speirs V, Walker RA: New perspectives into the biological and clinical relevance of oestrogen receptors in the human breast. J Pathol 2007 , 211:499-506

2. Moore JT, McKee DD, Slentz-Kesler K, Moore LB, Jones SA, Horne EL, Su JL, Kliewer SA, Lehmann JM, Willson TM: Cloning and characterisation of human estrogen receptor $\beta$ isoforms. Biochem Biophys Res Commun 1998, 247:75-78

3. Poola I, Abraham J, Baldwin K, Saunders A, Bhatnagar A: Estrogen receptors $\beta 4$ and $\beta 5$ are full length functionally distinct $E R \beta$ isoforms: cloning from human ovary and functional characterization. Endocrine 2005, 27:227-238

4. Leung Y-K, Mak P, Hassan S, Ho S-M: Estrogen receptor (ER)- $\beta$ isoforms: A key to understanding $E R \beta$ signaling. Proc Natl Acad Sci 2006, 103:13162-13167

5. Honma N, Horii R, Iwase T, Saji S, Younes M, Takubo K, Matsuura M, Ito $Y$, Akiyama F, Sakamoto G: Clinical importance of estrogen receptor- $\beta$ evaluation in breast cancer patients treated with adjuvant tamoxifen therapy. J Clin Oncol 2008, 26:3727-3734

6. Shaaban AM, Green AR, Karthik S, Alizadeh Y, Hughes TA, Harkins L, Ellis IO, Robertson JF, Paish EC, Saunders PT, Groome NP, Speirs V: Nuclear and cytoplasmic expression of ER $\beta 1$. ER $\beta 2$, and ER $\beta 5$ identifies distinct prognostic outcome for breast cancer patients Clin Cancer Res 2008, 14:5228-5235

7. Novelli F, Milella M, Melucci E, Di Benedetto A, Sperduti I, PerroneDonnorso R, Perracchio L, Venturo I, Nisticò C, Fabi A, Buglioni S, Natali PG, Mottolese $\mathrm{M}$ : A divergent role for estrogen receptor $\beta$ in node-positive and node-negative breast cancer classified according to molecular subtypes: an observational prospective study. Breast Cancer Res 2008, 10:R74

8. Lannigan DA: Estrogen receptor phosphorylation. Steroids 2003, 68:1-9

9. Skliris GP, Rowan BG, Al-Dhaheri M, Williams C, Troup S, Begic S, Parisien M, Watson PH, Murphy LC: Immunohistochemical validation of multiple phospho-specific epitopes for estrogen receptor $\alpha(E R \alpha)$ in tissue microarrays of $\mathrm{ER} \alpha$ positive human breast carcinomas. Breast Cancer Res Treat 2009, 118:443-453

10. Weigel, N: Steroid hormone receptors and their regulation by phosphorylation. Biochem J 1996, 319:657-667

11. Le GP, Montano MM, Schodin DJ, Katzenellenbogen BS: Phosphorylation of the human estrogen receptor. Identification of hormoneregulated sites and examination of their influence on transcriptional activity J Biol Chem 1994, 269:4458-4466

12. Ali S, Metzger D, Bornert JM, Chambon P: Modulation of transcriptional activation by ligand-dependent phosphorylation of the human oestrogen receptor A/B region. EMBO J 2003, 12:1153-1160

13. Kato $S$, Endoh H, Masuhiro $Y$, Kitamoto T, Uchiyama S, Sasaki H, Masushige S, Gotoh Y, Nishida E, Kawashima H, Metzger D, Chambon $\mathrm{P}$ : Activation of the estrogen receptor through phosphorylation by mitogen-activated protein kinase. Science 1995, 270:1491-1494

14. Murphy LC, Cherlet T, Adeyinka A, Niu Y, Snell L, Watson P: Phosphoserine-118 estrogen receptor- $\alpha$ detection in human breast tumors in vivo. Clin Cancer Res 2004, 10:1354-1359

15. Murphy LC, Niu Y, Snell L, Watson P: Phospho-serine-118 estrogen receptor- $\alpha$ expression is associated with better disease outcome in women treated with tamoxifen. Clin Cancer Res 2004, 10:5902-5906

16. Kok M, Holm-Wigerup C, Hauptmann M, Michalides R, Stahl O, Landberg G: Estrogen receptor- $\alpha$ phosphorylation at serine-118 and tamoxifen response in breast cancer. J Natl Cancer Inst 2009, 101:1725-1729

17. Jiang J, Sarwar N, Peston D, Kulinskaya E, Shousha S, Coombes R, Ali S: Phosphorylation of estrogen receptor- $\alpha$ at Ser167 is indicative of longer disease-free and overall survival in breast cancer patients. Clin Cancer Res 2007, 13:5769-76 
18. Yamashita H, Nishio M, Kobayashi S, Ando Y, Sugiura H, Zhang Z, Hamaguchi M, Mita K, Fujii Y, Iwase H: Phosphorylation of estrogen receptor $\alpha$ serine 167 is predictive of response to endocrine therapy and increases post relapse survival in metastatic breast cancer. Breast Cancer Res 2005, 7:R753-R764

19. Sarwar N, Kim JS, Jiang J, Peston D, Sinnett HD, Madden P, Gee JM, Nicholson RI, Lykkesfeldt AE, Shousha S, Coombes RC, Ali S: Phosphorylation of $\mathrm{ER} \alpha$ at serine 118 in primary breast cancer and in tamoxifen-resistant tumours is indicative of a complex role for $\mathrm{ER} \alpha$ phosphorylation in breast cancer progression. Endocr Relat Cancer 2006, 13:851-861

20. Holm C, Kok M, Michalides R, Fles R, Koomstra RNT, Wesseling J, Hauptmann M, Neefjes J, Peterse JL, Stahl O, Landberg G, Linn SC: Phosphorylation of the oestrogen receptor $\alpha$ at serine 305 and prediction of tamoxifen resistance in breast cancer. J Pathol 2009, 217:372-379

21. Yamashita H, Nishio M, Toyama T, Sugiura H, Kondo N, Kobayashi S, Fujii Y, Iwase H: Low phosphorylation of estrogen receptor $\alpha(E R \alpha)$ serine 118 and high phosphorylation of $\mathrm{ER} \alpha$ serine 167 improve survival in ER-positive breast cancer. Endocr Relat Cancer 2008, 15:755-763

22. Picard N, Charbonneau C, Sanchez M, Licznar A, Busson M, Lazennec G, Tremblay A: Phosphorylation of activation function-1 regulates proteasome-dependent nuclear mobility and E6-associated protein ubiquitin ligase recruitment to the estrogen receptor $\beta$. Mol Endocrinol 2008, 22:317-330

23. Tremblay GB, Tremblay A, Copeland NG, Gilbert DJ, Jenkins NA, Labrie F, Giguère V: Cloning, chromosomal localization, and functional analysis of the murine estrogen receptor $\beta$. Mol Endocrinol 1997, 11:353-365

24. St-Laurent V, Sanchez M, Charbonneau C, Tremblay A: Selective hormone-dependent repression of estrogen receptor $\beta$ by a p38activated ErbB2/ErbB3 pathway. J Steroid Biochem Mol Biol 2005, 94:23-37

25. Sanchez M, Picard N, Sauvé K, Tremblay A: Challenging estrogen receptor $\beta$ with phosphorylation. TEM 2009, 21:104-110

26. Sauvé K, Lepage J, Sanchez M, Heveker N, Tremblay A: Positive feedback activation of estrogen receptors by the CXCL12-CXCR4 pathway. Cancer Res 2009, 69:5793-800

27. Tremblay A, Tremblay GB, Labrie F, Giguere V: Ligand-independent recruitment of SRC-1 to estrogen receptor $\beta$ through phosphorylation of activation function AF-1. Mol Cell 1999, 3:513-519

28. Maraqa L, Cummings M, Peter MB, Shaaban AM, Horgan K, Hanby AM, Speirs V: Carcinoembryonic antigen cell adhesion molecule 6 predicts breast cancer recurrence following adjuvant tamoxifen. Clin Cancer Res 2008, 14:405-11

29. Waterworth A, Hanby A, Speirs V: A novel cell array technique for high-throughput cell-based analysis. In Vitro Cell Dev Biol Anim 2005, 41:185-187

30. Coleman LJ, Peter MB, Teall TJ, Brannan RA, Hanby AM, Honarpisheh $\mathrm{H}$, Shaaban AM, Smith L, Speirs V, Verghese ET, McElwaine $\mathrm{JN}$, Hughes TA: Combined analysis of elF4E and 4E-binding protein expression predicts breast cancer survival and estimates elF4E activity. Br J Cancer 2009, 100:1393-1399

31. Murphy LC, Skliris GP, Rowan BG, Al-Dhaheri M, Williams C, Penner $\mathrm{C}$, Troup S, Begic S, Parisien M, Watson PH: The relevance of phosphorylated forms of estrogen receptor in human breast cancer in vivo. J Steroid Biochem Mol Biol 2009, 114:90-95
32. Skliris GP, Parkes AT, Limer JL, Burdall SE, Carder PJ, Speirs V: Evaluation of seven oestrogen receptor $\beta$ antibodies for immunohistochemistry, Western blotting and flow cytometry in human breast tissue. J Pathol 2002, 197:155-162

33. Smith L, Brannan RA, Hanby AM, Shaaban AM, Verghese ET, Peter MB, Pollock S, Satheesha S, Szynkiewicz M, Speirs V, Hughes TA: Differential regulation of estrogen receptor $\beta$ isoforms by $5^{\prime}$ untranslated regions in cancer. J Cell Mol Med 2009, doi: 10.1111/j.1582-4934.2009.00867

34. Ogawa S, Inoue S, Watanabe T, Orimo A, Hosoi T, Ouchi Y, Muramatsu M: Molecular cloning and characterization of human estrogen receptor $\beta c x$ : a potential inhibitor of estrogen action in human. Nucleic Acids Res 1998, 26:3505-3512

35. Pettersson K, Delaunay F, Gustafsson J-A: Estrogen receptor $\beta$ acts as a dominant regulator of estrogen signalling. Oncogene 2000, 19: 4970-4978

36. Zhao C, Matthews J, Tujague M, Wan J, Ström A, Toresson G, Lam EW, Cheng G, Gustafsson JA, Dahlman-Wright K: Estrogen receptor $\beta 2$ negatively regulates the transactivation of estrogen receptor $\alpha$ in human breast cancer cells. Cancer Res 2007, 67:3955-3962

37. Tateishi $Y$, Kawabe Y, Chiba T, Murata S, Ichikawa K, Murayama A, Tanaka K, Baba T, Kato S, Yanagisawa J: Ligand-dependent switching of ubiquitin-proteasome pathways for estrogen receptor. EMBO $J$ 2004, 23:4813-4823

38. Tateishi $Y$, Sonoo R, Sekiya $Y$, Sunahara N, Kawano M, Wayama M, Hirota R, Kawabe Y, Murayama A, Kato S, Kimura K, Yanagisawa J: Turning off estrogen receptor B-mediated transcription requires estrogen-dependent receptor proteolysis. Mol Cell Biol 2006, 26:7966-7976

39. Sun J, Baudry J, Katzenellenbogen JA, Katzenellenbogen BS: Molecular basis for the subtype discrimination of the estrogen receptor- $\beta$-selective ligand, diarylpropionitrile. Mol Endocrinol 2003, 17:247-258

40. Kuiper GG, Carlsson B, Grandien K, Enmark E, Häggblad J, Nilsson $\mathrm{S}$, Gustafsson JA: Comparison of the ligand binding specificity and transcript tissue distribution of estrogen receptors $\alpha$ and $\beta$. Endocrinology 1997, 138:863-780

41. Park OJ, Surh YJ: Chemopreventive potential of epigallocatechin gallate and genistein: evidence from epidemiological and laboratory studies. Toxicol Lett 2004, 150:43-56

42. Limer JL, Parkes AT, Speirs V: Differential response to phytoestrogens in endocrine sensitive and resistant breast cancer cells in vitro. Int J Cancer 2006, 119:515-521

43. Rai D, Frolova A, Frasor J, Carpenter AE, Katzenellenbogen BS: Distinctive actions of membrane-targeted versus nuclear localized estrogen receptors in breast cancer cells. Mol Endocrinol 2005, 19: $1606-1617$

44. van't Veer LJ, Dai $H$, van de Vijver MJ, He YD, Hart AA, Mao M, Peterse HL, van der Kooy K, Marton MJ, Witteveen AT, Schreiber GJ, Kerkhoven RM, Roberts C, Linsley PS, Bernards R, Friend SH: Gene expression profiling predicts clinical outcome of breast cancer. Nature 2002, 415:530-536

45. Sotiriou C, Pusztai L: Gene-expression signatures in breast cancer N Engl J Med 2009, 360:790-800

46. Rakha A, Reis-Filho JS, Ellis IO: Combinatorial biomarker expression in breast cancer. Breast Cancer Res Treat 2010, doi: 10.1007/s10549010-0746-X

47. Skliris GP, Nugent ZJ, Rowan BG, Penner CR, Watson PH, Murphy LC: A phosphorylation code for oestrogen receptor alpha predicts clinical outcome to endocrine therapy in breast cancer. Endo Rel Cancer, 2010, 17:589-597 